\title{
Рынок электронной коммерции в Казахстане: анализ состояния и направления развития
}

\author{
А.Б. Жанбозова ${ }^{1}$, Т.А. Азатбек ${ }^{2}$, С.Н. Валиева ${ }^{3}$, И.Н. Тузелбаева ${ }^{3}$, К.Б. Жуманазаров ${ }^{4}$ \\ ${ }^{1}$ Институт экономики КН МОН РК, ${ }^{2}$ ЕНУ им. Л.Н. Гумилёва, ${ }^{3}$ Казахский университет экономики, \\ финансов и международной торговли, ${ }^{4}$ Казахский университет технологии и бизнеса
}

\section{Аннотация}

Сегодня глобальный мир характеризуется активным развитием и повсеместным проникновеним информационно-коммуникативных технологий в различные сферы жизнедеятельности. Эта тенденция также повлияла на способы и форматы ведения бизнеса: сегодня уже активно развивается электронная коммерция, которая предоставила новые перспективы развития для бизнеса в виде экономии на транскционных издержках, возможности доступа к глобальным рынкам без необходимости присутствия на месте и т.д.

Целью статьи является выявление барьеров развития рынка электронной коммерции Республики Казахстан и разработка предложений по их устранению.

В статье исследованы проблемы и причины недостаточного уровня развития электронной коммерции в Казахстане посредством проведения анализа состояния рынка электронной коммерции и основных факторов, определяющих темпы его развития. Выявлены причины низкой предпринимательской активности на исследуемом рынке с определением правовых, инфраструктурных и других барьеров развития. Результаты исследования могут быть использованы в качестве основы для регулирования рынка электронной коммерции. В частности, они могут быть использованы для разработки и реализации программ в области стимулирования предпринимательской активности на рынке электронной коммерции и улучшения ее инфраструктуры.

Ключевые слова: конкурентоспособность в интернет-экономике, электронная коммерция, маркетплейсы, государственное регулирование рынка электронной коммерции, трансграничная электронная коммерция.

\section{Қазақстандағы электрондық коммерция нарығы: жағдайды талдау және даму бағыттары}

\section{Түйін}

Қазіргі кезде жаһандық әлем өмірдің әртүрлі салаларына ақпараттық-коммуникациялық технологиялардың кеңінен енуімен және белсенді дамуымен сипатталады. Бұл үрдіс бизнесті жүргізу тәсілдері мен нысандарына да әсер етті: қазіргі уақыттың өзінде электронды коммерция белсенді дамып келеді, бұл бизнес үшін трансакциялық шығындарды үнемдеу, нақты орналасусыз әлемдік нарықтарға шығу сияқты жаңа мүмкіндіктерді ашты.

Мақаланың мақсаты Қазақстан Республикасындағы электронды сауда нарығының дамуындағы кедергілерді анықтау және оларды жою бойынша ұсыныстар әзірлеу болып табылады.

Мақалада электронды сауда нарығының жағдайын және оның даму қарқынын анықтайтын негізгі факторларды талдау арқылы Қазақстандағы электронды сауданың жеткіліксіз даму деңгейінің мәселелері мен себептері қарастырылған. Зерттелетін нарықтағы кәсіпкерлік белсенділіктің төмен деңгейінің себептері анықталып, оның дамуының құқықтық, инфрақұрылымдық және басқа да кедергілері айқындалды. Зерттеу нәтижелері электронды сауда нарығын реттеу үшін негіз бола алады. Атап айтқанда, олар электронды сауда нарығында кәсіпкерлік қызметті ынталандыру және оның инфрақұрылымын жақсарту бағдарламаларын әзірлеу және іске асыру үшін пайдаланылуы мүмкін.

Түйін сөздер: Интернет-экономикадағы бәсекеге қабілеттілік, электронды сауда, маркетплейстер, электронды сауда нарығын мемлекеттік реттеу, трансшекаралық электрондық коммерция.

\section{The e-commerce market in Kazakhstan: analysis of the state and development directions}

\section{Abstract}

Today, the global world is characterized by active development and widespread penetration of information and communication technologies into various spheres of life. This trend has also influenced the ways and formats of doing business: today, e-commerce is already actively developing, which has provided new development prospects for business in the form of savings on transaction costs, the ability to access global markets without the need to be present on the spot, etc.

The purpose of the article is to identify barriers to the development of the e-commerce market in the Republic of Kazakhstan and develop proposals for their elimination. The article examines the problems and reasons for the insufficient level of development of e-commerce in Kazakhstan by analyzing the state of the e-commerce market and the main factors that determine the pace of its development. The reasons for low entrepreneurial activity in the investigated market are identified, with the definition of legal, infrastructural and other barriers to development. The research results can be used as a basis for regulating the e-commerce market. In particular, they results can be used to develop and implement programs to stimulate entrepreneurial activity in the e-commerce market and improve its infrastructure. 
Keywords: competitiveness in the Internet economy, e-commerce, marketplaces, government regulation of the e-commerce market, cross-border e-commerce.

\section{Введение}

Повсеместное влияние цифровизации кардинальным образом меняет способ взаимодействия людей, бизнеса и государства. Новый этап глобального развития характеризуется перемещением данных через национальные границы, вследствие чего меняются характер, модели международной торговли. Несмотря на существование электронной торговли уже на протяжении многих лет, нынешние масштабы этих операций несоизмеримы с прежними. Кроме того, появление онлайн платформ кардинально поменяло правила игры, вызывая преобразование процессов ведения коммерции.

Рынок электронной коммерции не имеет географических границ, а его субъекты вынуждены функционировать практически в одинаковых условиях. В то же время, происходящие процессы укрупнения субъектов рынка электронной коммерции в Казахстане всё больше создают сложности для входа на рынок новых отечественных компаний, особенно малых. Одним из самых крупных субъектов электронной коммерции в РК является АО «Казпочта», которое уже несколько лет осуществляет попытку интегрирования интернет-заказов внутри Казахстана. Предпринимаемые сегодня Правительством РК меры по развитию инфраструктуры информационно-коммуникативных технологий в рамках реализации проекта «Цифровой Казахстан» способствуют повышению спроса на услуги и товары электронной коммерции. В то же время казахстанцы все чаще начали покупать товары у зарубежных интернетпоставщиков. В этой связи Казахстану необходимо стимулировать активность отечественных компаний в секторе электронной коммерции и создать условия для повышения уровня их конкурентоспособности. В этом плане роль государства является ключевой.

\section{Литературный обзор}

Первостепенное значение для достижения цели настоящей работы имеют исследования, непосредственно направленные на концептуализацию трансформации экономических отношений в контексте формирования интернет-экономики. Толкование данных вопросов достаточно широко представлено в работах Д. Белла [1], П. Эванса и Т. Урстера [2], Е. Лимера и М. Сторпера [3], Н. Чернихв и др. [4], М.Портера [5], Р. Литана и А. Ривлина [6] и др.

Концепция самой электронной коммерции начала разрабатываться еще в прошлом веке. Д. Козье в 1990 году первым предоставил наиболее полную интерпретацию феномена e-commerce» [7]. В его работе анализ и оценка происходящих в электронной коммерции процессов осуществляется на примере успешных компаний, а отдельные главы посвящены роли новых технологий в электронной коммерции и вопросам обеспечения безопасности. Несмотря на то, что работа Д. Козье является основополагающей в данном направлении, она больше представляет собой инструментальную методику создания и развития компании в сфере электронной коммерции.

В дальнейшем удачные попытки систематического изложения и обогощения теории электронной коммерции были предприняты в работах Д. Эймора [8], М. Хэйга [9], П. Гари [10] и др. Вопросы электронной коммерции с экономической точки зрения рассматривались Р. Фрибергом, М. Гансландтом, М. Сандрстомом[11,12], М. Смитом и др. [13], Р. Кауфманом и Е. Уолденом [14]. Р. Кауфман и Е. Уолден осуществили попытку построения новой основы для понимания исследований электронной коммерции и определили диапазон применимых существующих теорий в текущих исследованиях в контексте новой концептуальной модели развития экономики.

Наиболее заметный вклад в становление концепции развития электронной коммерции среди российских ученых внесли О.А. Кобелев [15], И.Т. Балабанов [16], А. М. Грехов [17], М. В. Климченя [18]. В работах этих ученых изложены основные принципы, системы и формы, а также организационные и правовые основы электронной коммерции. При этом определение термина «электронная коммерция» в наиболее современном понимании было сформировано О.А. Кобелевым, согласно которому «электронная коммерция - это сфера экономики, которая включает в себя все финансовые и торговые транзакции, осуществляемые при помощи интернета, и бизнес-процессы, связанные с проведением таких транзакций [19].

Следует заметить, что исследованию сущности и особенностей развития электронной коммерции было посвящено множество 
работ ученых дальнего и ближнего зарубежья. Основная масса этих публикаций носит ознакомительный характер и рассматривает отдельные составляющие электронной коммерции без характеристики комплексного анализа системы в целом. Кроме того, многие из этих исследований проведены обобщенно, часто дублируют друг друга и не обладают достаточной научной основой для проработки вопросов их применения в развивающихся странах.

Вместе с тем, привлекают внимание в аспекте проблематики нашего исследования работы В.В. Царева [20], Л.Д. Реймана [21] и Д. Сигела [22], в которых были подробно изучены пути решения проблем создания эффективных систем электронной коммерции. Эти работы наиболее полно отразили специфику предпринимательской деятельности в сфере электронной коммерции. Особый акцент в этих работах был сделан на развитие информационно-коммуникативных технологий как важной инфраструктуры, необходимой для развития электронной коммерции.

Новая полоса изысканий в области исследования электронной коммерции была представлена в работах А. Савельева [23], В.В. Дика [24], И.А. Крымского и К.В. Павлова [25], в которых был изучен процесс трансформации коммерции с традиционной формы в электронную в развитых странах, описаны особенности правового регулирования трансграничной электронной коммерции.

Для получения более полной характеристики процесса развития электронной коммерции особый интерес представляет работа И.А Стрельца, в котором были исследованы вопросы влияния электронной коммерции на характер экономических отношений. По его утверждению, изменения кроются в формировании транснациональных кластеров в виртуальной среде, которые выступают площадкой для налаживания связи c другими производителями и потребителями [26]. В настоящее время подобными кластерами выступают специализированные электронные площадки, именуемые «маркетплейсами», «онлайновыми площадками» или «цифровыми площадками» электронной коммерции. Х.Г. Ли и Т.Х. Кларк отмечают, что данные площадки часто находятся вне юрисдикции отдельных государств, обладая бо́льшей конкурентоспособностью в сравнении с традиционными экономическими субъектами [27]. В этих условиях сущность конкурентоспособности значительно трансформируется: если конкурентоспособность в традиционной экономике зависела от производственного потенциала и технологических разработок, то в интернет-экономике конкурентоспособность определяется развитием инфраструктуры электронной коммерции.

Иными словами, без доступа к глобальному рынку, который представляет электронная коммерция, традиционные экономические факторы конкурентоспособности будут бесполезны. Таким образом, исследуя суть экономических отношений в электронной коммерции, мы наблюдаем трансформацию самой теории конкурентных преимуществ в интернет-экономике. Здесь уместно процитировать Ф. Котлера и Г. Армстронга, которые обозначили, что «конкурентные позиции компании на местном и национальном рынках определяются их глобальными позициями» [28]. Согласно их мнению, трансформация традиционных отраслей производства в глобальные отрасли является единственным путем обретения конкурентных преимуществ. Подобную точку зрения разделял и Р. Котч, который также справедливо отметил тенденцию разделения информационных и товарных потоков, когда сделки виртуализируются и совершаются независимо от местонахождения товара [29]. При этом, по его мнению, приоритетное развитие экономик будет происходить за счет глобального перераспределения информационных потоков.

Таким образом, электронная коммерция позволяет стать частью глобальной цепочки поставок без необходимости создания производств или центров продаж, складов в стране реализации продукции, что дает возможность сокращать трансакционные издержки и количество посредников. Вместе с тем, электронная коммерция вытесняет традиционную оптово-розничную торговлю. Здесь уместно вспомнить про высказывание С.Боулза, который отмечал, что «институциональное вытеснение происходит, когда присутствие одного института нарушает функционирование другого» [30]. Действительно, опыт развитых стран показывает, что активное развитие электронной коммерции приводит к закрытию традиционных магазинов из-за разницы в ценовой политике, обусловленных бо́льшими затратами субъектов традиционной коммерции на аренду, заработную плату и т.д. Здесь необходимо понимать, что рост электронной коммерции будет происходить в ущерб традиционной торговле. Полагаем, со временем границы между розничной электронной коммерцией и ритейлом будут стираться, так как все современные традиционные магазины имеют 
собственные сайты продаж или интегрированы в электронные каналы продаж. Собственно, им все ровно, где продавать - в магазине или в интернете. При условии наличия в стране продаж налоговых льгот на электронную коммерцию, формат онлайн-торговли будет преобладать. В этой связи, возникает вопрос о том, насколько целесообразно развивать сферу электронной коммерции, если она затесняет сферу традиционного ритейла.

Если абстрагироваться, что страна условно закрыта для международной торговли, то особенных усилий от государства по стимулированию электронной коммерции не требуется. Конкурентная среда сама будет заставлять производителей продавать в интернете в погоне за покупателями, которые будут покупать то, что дешевле, при этом заказывая доставку на дом и не теряя времени на посещение магазина. С другой стороны, современные реалии таковы, что мы являемся частью глобального мира, и, соответственно, открыты для международной торговли. Это означает, что если мы сами не будем переходить на электронную коммерцию и не будем вытеснять традиционную торговлю, то это сделают зарубежные поставщики за нас, следовательно, весь потребительский рынок для нас будет потерян.

Таким образом, в современных условиях дивиденды от развития электронной коммерции могут концентрироваться в других странах, а убытки от сопутствующей деградации традиционной торговли - в иных. Как отмечает Э. Дж. Бергер, электронная коммерция сегодня «один из последних участков, где бизнес может получить преимущества, и место для будущей глобальной конкуренции» [31]. Исходя из этого, государственное вешательство в сферу электронной коммерции является оправданным. При этом регулирование должно быть направлено на выравнивание конкурентных условий для зарубежных и отечественных поставщиков, на создание необходимой инфраструктуры электронной коммерции, а также стимулирование предпринимательской активности отечественных предприятий в сфере электронной коммерции путем предоставления налоговых льгот и иных мер поддержки.

Наряду с этим, необходимость нормативно-правового регулирования сферы электронной коммерции продиктована также и изменением институционального содержания экономических отношений. Трансграничный характер электронной коммерции, обязательства государств в рамках интеграционных союзов и других международных соглашений усложняют разработку эффективных инструментов регулирования сферы электронной коммерции. На наш взгляд, регулирование должно быть направлено на приоритетное развитие электронной коммерции, в частности, на стимулирование местных предпринимателей на занятие электронной коммерцией, а также на принятие временных ограничительных мер в отношении глобальных игроков рынка электронной коммерции путем применения тарифных инструментов регулирования. При этом необходимо понимать, что электронная коммерция не способна принести большие бюджетные доходы. Главная цель регулирования заключается в содействии в продвижении отечественной продукции на внутренний и зарубежные рынки.

М.Л. Калужский выделяет следующие институциональные особенности электронной коммерции, затрудняющих ее налогообложение и нормативно-правовое регулирование [32]:

1) отсутствие географических границ электронной коммерции;

2) анонимность продавцов и нематериальность виртуальных представительств, не позволяющая идентифицировать их местонахождение;

3) анонимная природа электронных сделок, так как платежные системы проводят платежи за товары как частные денежные переводы (банки), либо вообще находятся вне правового поля (платежные провайдеры);

4) анонимность клиентов, не позволяющая продавцу точно определить правовой статус клиента (физическое или юридическое лицо, цель покупки и т.д.).

Проблемы налогообложения субъектов электронной коммерции были подробно освещены в работах Р. Дорнберга и Л. Хиннекенса [33], К. Фридена [34], У. Хеллерстейна [35]. В этих же работах предложены принципы построения эффективной системы налогового контроля, позволяющие учитывать особенности ведения электронной коммерции. Проблема налогообложения электронной коммерции является предметом многих зарубежных исследований, а его основные принципы были разработаны документами ОЭСР. Следует отметить, что эти аспекты не могут быть полностью перенесены на казахстанскую действительность в силу ее специфики и нуждаются в критической переоценке и адаптации.

Проблема состоит в том, что «в современном налоговом законодательстве не существует эффективных методов налогового контроля, которые могут быть использованы в целях выявления субъектов электронной 
коммерции, уклоняющихся от постановки на налоговый учет, либо занижающих величину фактически полученных доходов» [36]. Это относится не только к Казахстану, но и практически ко всем без исключения другим странам мира [37].

Проведенный обзор позволяет констатировать, что среди опубликованных работ в сфере электронной коммерции отсутствуют исчерпывающие положения, обобщающие на теоретическом и практическом уровнях результаты и проблемы формирования и развития рынка электронной коммерции. Практически не существует исследований, посвященных разработке механизмов и инструментов стимулирования электронной коммерции внутри рынка, представляющих углубленный научный анализ.

\section{Методы исследования}

В исследовании реализован комплексный подход к анализу рынка электронной коммерции, базирующийся на общенаучных методах исследования, которые включают методы сравнительного анализа, обобщение, систематизацию, метод эмпирического исследования, историко-логический метод. Изучение рынка электронной коммерции осуществлено путем проведения анализа конъюнктуры и динамики развития рынка электронной коммерции РК; определения казахстанского содержания в общем объеме онлайн-покупок казахстанцев; анализа показателей Индекса готовности к электронной коммерции в сегменте «бизнес-потребитель», опубликованного Конференцией $\mathrm{OOH}$ по торговле и развитию. Для выявления барьеров развития электронной коммерции, по основным четырем индикаторам данного Индекса проведен более глубокий анализ. В целях разработки предложений по совершенстованию институциональных мер стимулирования электронной коммерции в Казахстане, проведен анализ инструментов государственной поддержки бизнеса в исследуемой сфере. В качестве информационной базы были использованы нормативно-правовые акты Республики Казахстан в области электронной коммерции, цифровизации, официальные данные Комитета по статистике Министерства национальной экономики РК по внутреннему рынку электронной коммерции, а также данные Национального банка РК по показателям трансграничной электронной коммерции.

\section{Результаты и обсуждение}

В настоящее время рынок электронной коммерции Казахстана находится на стадии активного развития. Объем рынка за последний пятилетний период вырос почти в три раза, достигнув в 2019 году 436,1 млрд. тенге (рисунок 1). При этом наибольший рост наблюдается в секторе розничной электронной торговли (более чем в 4 раза).

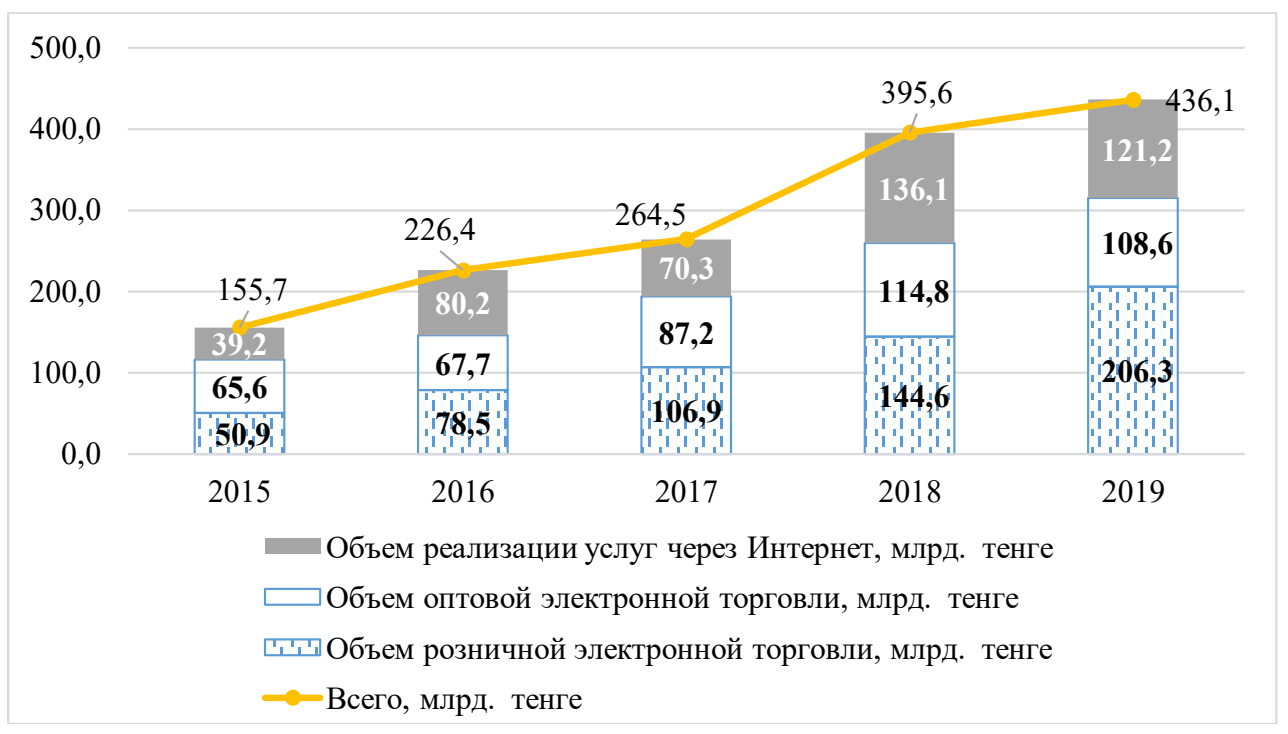

Примечание - Составлено по данным Комитета по статистике МНЭ РК

Рисунок 1 - Структурная динамика развития внутреннего рынка электронной коммерции Казахстана 
Согласно данным Комитета по статистике МНЭ РК, в 2019 г. в Казахстане доля розничной электронной торговли в общей структуре розничной торговли составляет $1,8 \%$. Для сравнения: в России данный показатель составляет $6 \%$, в Китае - 37\%, в Великобритании - 22\%, в США - 11\% [38]. Как видим, показатели Казахстана довольно малы, поэтому можно сделать вывод, что потенциал роста рынка еще в полной мере не используется.
Кроме того, на сегодняшний день казахстанцы все больше переключаются на международные площадки электронной коммерции: в 2019 г. количество покупок возросло с 4,8 млн. единиц в 2016 г. до 15,9 млн. единиц. Отток средств казахстанцев за рубеж создает определенную угрозу для роста неокрепшего внутреннего рынка электронной коммерции Казахстана. Соотношение объемов трансграничных и внутренних онлайн-покупок казахстанцев в 2015-2019 гг. представлено в таблице 1.

Таблица 1 - Соотношение объемов трансграничных и внутренних онлайн-покупок казахстанцев

\begin{tabular}{|l|c|c|c|c|c|c|c|c|c|c|}
\hline \multirow{2}{*}{$\begin{array}{c}\text { Объем онлайн-покупок } \\
\text { казахстанцев }\end{array}$} & 2015 & 2016 & 2017 & 2018 & 2019 & \multicolumn{5}{|c|}{ Доля в общей структуре } \\
\cline { 6 - 11 } & & & & & & 2015 & 2016 & 2017 & 2018 & 2019 \\
\hline $\begin{array}{l}\text { Трансграничная электронная } \\
\text { коммерция, млрд.тг. }\end{array}$ & 53.9 & 76.3 & 108.9 & 126.9 & 172.2 & $25,7 \%$ & $25 \%$ & $29 \%$ & $24 \%$ & $28 \%$ \\
\hline Внутренний рынок, млрд.тг. & 155.7 & 226.4 & 264.5 & 395.6 & 436.1 & $74,3 \%$ & $75 \%$ & $71 \%$ & $76 \%$ & $72 \%$ \\
\hline Всего & 209.6 & 302.7 & 373.4 & 522.5 & 608.2 & $100 \%$ & $100 \%$ & $100 \%$ & $100 \%$ & $100 \%$ \\
\hline
\end{tabular}

Примечание - Рассчитано авторами на основе данных Национального банка РК и Комитета по статистике МНЭ РК

По данным таблицы, за 2015-2019 гг. объем заказов казахстанцев у зарубежных онлайн-поставщиков вырос в 3,19 раз, тогда как объем интернет-покупок внутри страны за рассматриваемый период вырос в 2,80 раз. Таким образом, темпы трансграничных онлайн-покупок казахстанцев опережают темпы внутренних онлайн-покупок. В 2019 г. из 100 тенге совершенных казахстанцами онлайн-покупок 72 тенге остались в Казахстане, в 2018 г. - 76 тенге. Учитывая, что казахстанские предприниматели еще не являются полноценными участниками глобальных цепочек поставок электронной коммерции, а также отсутствие собственных серьезных цифровых платформ электронной коммерции, вышеуказанная тенденция вызывает определенные опасения. Без принятия мер, направленных на поддержку местных предпринимателей-субъектов электронной коммерции и в целом на стимулирование данного вида деятельности Казахстан может полностью потерять контроль над своим собственным рынком электронной коммерции.

Показателем, характеризующим развитие электронной коммерции в стране выступает уровень электронной вовлеченности населения. Под электронной вовлеченностью населения понимается готовность населения совершать онлайн-покупки [39]. Электронная вовлеченность населения Казахстана растет довольно быстрыми темпами. По данным
Комитета по статистике МНЭ РК, количество интернет пользователей Казахстана в 1997 году составляло всего 41,1 тыс. чел., а первый миллион пользователей интернета был зафиксирован в 2005 году. В настоящее время доля пользователей сети Интернет в возрасте от 16 лет и выше составляет $81,3 \%$ от всего населения. Анализ уровня компьютерной грамотности населения показал, что в целом по Казахстану $57,1 \%$ населения являются обычными пользователями, тогда как 6,8\% - продвинутыми пользователями, 23,5\% начинающими пользователями. Наибольшая доля продвинутых пользователей наблюдаются в городах Нур-Султан и Алматы, а также в Туркестанской области.

В 2019 году в рейтинге развития электронной коммерции UNCTAD B2C Ecommerce Index Казахстан занимает 57 место среди 152 стран мира (68,5 баллов из 100, ранее в 2018 году - 53 место) (рисунок 2). Согласно отчету, Казахстан относится к категории стран с высоким уровнем готовности к электронной торговле.

Индекс состоит из четырех показателей: уровень распространения Интернета, число защищенных серверов на 1 миллион жителей, уровень распространения банковских карт и уровень надежности почтовой системы. 


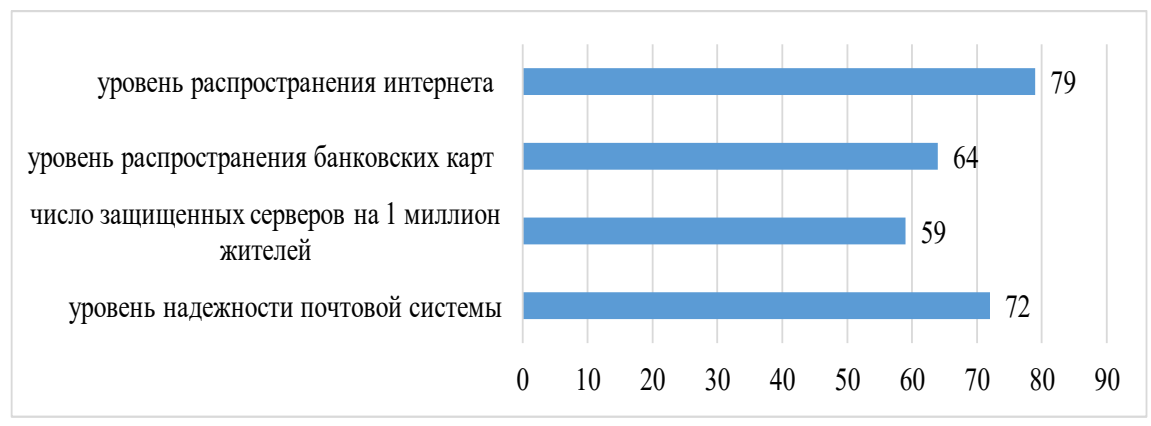

Примечание - Составлено по источнику [40]

Рисунок 2 - Показатели Казахстана в в рейтинге UNCTAD B2C E-commerce Index 2019

1. В Казахстане уровень распространения интернета является довольно высоким. Кроме того, сравнительно невысокие цены на услуги интернет-провайдеров положительно способствуют ее более глубокому проникновению. Вместе с тем, в регионах распространенность интернета довольно сильно отличается. Так, до 2020 года интернетом были обепечены только 200 сельских территорий Казахстана. В течение 2020 года 5 тыс. сельских населенных пунктов были обеспечены доступом к интернету $3 \mathrm{G}$ или $4 \mathrm{G}$. Вместе с тем, в большинстве из них имеется только доступ к мобильному интернету. Волоконно-оптические линии связи проведены лишь в 1,2 тыс. сельских населенных пунктах. В настоящее время 1,1 тыс. сельских населенных пунктов Казахстана, где проживает более 130 тыс. человек, не имеют доступ к интернету [41]. По плану профильного министерства в 2021-2022 годах к широкополосному интернету по технологии 3G/4G будут подключены 877 сел с населением менее 250 человек, остальные 930 сел - к спутниковому интернету. Реализация этих мероприятий играет первостепенную роль для увеличения спроса на электронные покупки, так как в настоящее время отдаленные регионы Казахстана не имеют доступ к высокоскоростным сетям, соответственно, лишены возможностей совершения онлайн покупок.

2. Согласно UNCTAD B2C E-commerce Index 2019, уровень распространения банковских карт в Казахстане оценивается в 64 балла из 100. Развитость безналичной системы платежей существенно влияет на уровень развитости электронной коммерции, так как основным инструментом оплаты покупок являются банковские карты. По данным Национального Банка РК, на 1 октября 2018 года в обращении находилось 21,3 млн платежных карточек, а количество держателей карточек составило 17,5 млн человек. При этом $52,4 \%$ от общего объема безналичных плате-жей была совершена посредством интернета. После введения в законодательное поле правил, регулирующих деятельность систем электронных денег на казахстанском рынке, появились системы электронных денег. В соответствии с Законом РК от 26 июля 2016 года № 11-VI «О платежах и платежных системах» эмитентами электронных денег могут выступать только банки второго уровня ${ }^{1}$. В настоящее время на рынке Казахстана функционируют двадцать пять систем электронных денег, эмитентами которых являются 10 банков и $\mathrm{AO}$ «Казпочта». В 2019 году начали функционировать восемь новых систем электронных денег: «Senim», «AlmaPay», «Onay Pay», «One Click», «КАЗЕВРОМОБАЙЛ», «Innoforce systems», «WebMoney Kazakhstan» и «Silkpay». Самыми крупными системами электронных денег, занимающими более 90\% данного сегмента рынка, являются: «Kaspi Bank», «VISA QIWI WALLET», «WOOPPAY», «Личная касса» и «W1 Kazakhstan».

3. Согласно UNCTAD B2C E-commerce Index 2019 по субиндексу число защищенных серверов на 1 млн. жителей Казахстан набрал всего 59 баллов из 100 возможных. По данным UNCTAD, 72\% всех стран уже приняли законодательство в области борьбы с киберпреступлениями. В Казахстане подобного

\footnotetext{
1 Закон РК от 26 июля 2016 года № 11-VI «O платежах и платежных системах» // «Казахстанская правда» от 10 августа 2016 г. № 152 (28278)
} 
Закона нет, но борьба с киберпреступлениями регламентируется статьями 205-213 Уголовного кодекса РК и другими подзаконными актами. С 2018 года началась реализация программы кибербезопасности «Киберщит Казахстана», которая рассчитана до 2022 года². Несмотря на принятые меры, еще остаются сферы деятельности, требующие регулирования со стороны государства. Так, например, в Казахстане большая часть населения в целях экономии средств использует нелицензионный софт. Более того, даже коммерческие организации пренебрегают покупать лицензионное програмное обеспечение. Здесь целесообразно установить высокие штрафы в случае использования подобных софтов юридическими лицами. В отношении физических лиц применение штрафов не является действенным инструментом из-за низкой покупательской способности существенной доли населения. В качестве мер косвенного воздействия можно рекомендовать мероприятия по повышению компьютерной грамотности населения. Существующие в настоящее время обучающие центры ориентированы на нужды предпринимателей. Для информационного охвата большей части населения на востребованных каналах телевидения необходимо размещать на периодической основе социальные обучающики ролики о видах интернет-мошенничества и мерах предосторожности.

4. Уровень надежности почтовых систем. На рынке Казахстана присутствуют как крупнейшие мировые компании (DHL), так и крупные местные компании с богатым опытом и репутацией (КазПочта, Алем Тат и проч.). Крупный национальный оператор почтовой службы Казахстана АО «Казпочта» за последние 5 лет добилось неплохих результатов в своей деятельности и вносит огромный вклад в трансграничную электронную коммерцию. В январе 2019 года АО «Казпочта» приняло рекордное количество посылок - 2 млн. Из них 1 млн. 700 тыс. - зарубежные поступления, а 300 тыс. казахстанские. Для сравнения: в январе 2017 года АО «Казпочта» приняло всего 500 тыс. посылок. Несколько лет назад на сайте национального почтового оператора появилась функция отслеживание груза. Однако скорость обработки заявок и осуществления доставок почтовых служб Казахстана уступают почто-

\footnotetext{
2 Постановление Правительства Республики Казахстан от 30 июня 2017 года № 407 Об утверждении Концепции кибербезопасности («Киберщит Казахстан») - URL: https://online. zakon.kz/Document/?doc_id=39754354 (дата обращения: 29.08.2020)
}

вым службам Китая. Во многом это обусловлено отставанием местных почтовых служб в плане внедрения инноваций и автоматизации процессов. Кроме того, почтовые службы в РК не несут материальную ответственность в случае задержки доставки товаров и т.д. Отсутсвие жесткой конкуренции на рынке почтовых услуг Казахстана значительно тормозит развитие этого рынка.

В целях комплексного решения проблем, сдерживающих развитие электронной коммерции, Правительством Казахстана разработана и утверждена Дорожная карта по развитию электронной торговли на 20182020 годы, согласно которой предусмотрено 7 основных направлений развития отрасли:

- совершенстование государственного регулирования электронной коммерции;

- развитие платежных систем в электронной торговле;

- повышение цифровой и финансовой грамотности населения и предпринимателей в электронной торговле;

- информационное сопровождение электронной торговли;

- развитие инфраструктуры логистики;

- повышение позиции Казахстана в международном рейтинге развития электронной коммерции UNCTAD;

- создание новых рабочих мест.

Реализация мероприятий, заложенных в Дорожной карте развития электронной торговли РК, в целом направлена на увеличение безналичных форм расчета, сокращение теневого оборота, повышение потенциала для интеграции в международную торговлю.

В рамках реализации данных направлений в Налоговом кодексе РК от 2018 года законодательно определены понятия «электронная торговля товарами», «интернетмагазин», «интернет-площадка». В целях создания благоприятной бизнес-среды и стимулирования развития электронной торговли, юридические лица и индивидуальные предприниматели освобождены от уплаты корпоративного и индивидуального подоходного налогов до 2023 года.

Такие льготы в том или ином виде есть во многих странах. В 1997 году в США еще при Клинтоне был принят закон «О свободе Интернета от налогообложения», согласно которому все интернет-магазины были освобождены от налогов с продаж. В результате этих преференций, интернет-экономика США росла, в разы опережая офлайн. Таким образом, происходил рост объемов интернетторговли в ущерб росту традиционной торгов- 
ли. Учитывая эту тенденцию, начиная с 2014 года отдельные штаты США начали отменять запрет на облажение налогом субъектов электронной коммерции. В Казахстане и странах ЕАЭС аналогом налога с продаж является налог на добавленную стоимость (НДС). Ассоциацией казахстанского интернетсообщества Казахстана уже несколько лет предлагается отменить НДС на три года для магазина, в случае если покупка прошла онлайн. По утверждению их представителей, такие меры способны подтолкнуть местных бизнесменов переходить на элетронную коммерцию в целом, а также позволить вывести наличные из теневого оборота. Действительно, в отчете UNCTAD констатируются следующие факты: 15\%-ное увеличение использования электронных платежей приводит к 7\%-ному сокращению объема теневой экономики. Кроме того, приверженцы отмены НДС в Казахстане ссылаются на относительно небольшую долю объема электронной коммерции в общем объеме розничных продаж, что не предполагает значительную потерю бюджета.

На наш взгляд, освобождение от НДС субъектов электронной коммерции нецелесообразно как минимум по двум причинам:

1. Характер взрывного роста электронной коммерции предполагает, что в обозримом будущем объем онлайн-покупок, с учетом предпринимаемых мер Правительством РК, будет расти, а это будет происходить за счет снижения традиционных розничных продаж. Следовательно, потери бюджета не могут быть незначительными.

2. Присутствие на рынке электронной коммерции Казахстана зарубежных субъектов электронной коммерции наряду с обязательствами Казахстана, связанными со вступлением в ВТО, не позволяют вести протеционистскую политику в отношении местных субъектов электронной коммерции. Кроме того, зарубежные онлайн-магазины, которые не имеют физического присутствия в Казахстане, не оплачивают подоходный налог, а НДС является единственным источником взимания платежей с них в бюджет страны. Таким образом, отмена НДС будет распространяться на все субъекты электронной коммерции, что во-первых, снижает налогооблагаемую базу, во-вторых, ставит местных предпринимателей в неравные конкурентные условия с зарубежными субъектами электронной коммерции.

Вышеприведенные утверждения позволяют сделать вывод о том, что для стимулирования отечественных предприни- мателей отмена подоходного налога является эффективным инструментом. Однако на практике применение данного инструмента не показало достаточную эффективность. Так, в 2018 году количество малых и средних предприятий в сфере электронной коммерции составляло 1698 единиц, из которых подали заявку на налоговые льготы всего 50 компаний (2,9\% от общего числа). По нашему мнению, причину этого явления следует искать в условиях получения этих льгот. Согласно Налоговому кодексу РК, для получения этих преференций, необходимо выполнение предприятиями следующих условий:

- оформление сделок по реализации товаров в электронном виде;

- произведение оплат за товары безналичным платежом не менее $90 \%$ от общего объема доходов;

- наличие собственной службы доставки товаров покупателю (получателю), либо наличие договоров с лицами, осуществляющими услуги по перевозке грузов, курьерскую и (или) почтовую деятельность.

Если первое и третье требования вполне приемлемы для выполнения, то выполнение требования, предполагающего произведение оплат за товары безналичным платежом не менее 90\% от общего объема доходов, достаточно трудновыполнимо для начинающих предпринимателей. Так, по данным Национальной палаты предпринимателей Казахстана, доля безналичного оборота большинства предприятий электронной коммерции не превышает 35\%. В этой связи считаем необходимым снизить порог безналичного оборота для малых и средних предприятий с 90 до $50 \%$ с ежегодным увеличением на 7-8\%. Такие поправки позволят охватить налоговыми льготами большее количество МСБ электронной коммерции, и будут способствовать росту рынка электронной коммерции и сокращению теневого оборота.

Мировая практика развития электронной коммерции показала, что ее положительная динамика происходит в основном за счет развития электронных торговых площадок, которые позволят бизнесменам экономить средства на создании сайта, внедрении системы безналичных платежей, услугах службы доставки и прочем. Их удобство заключается в формировании на единой площадке полного комплекса услуг, как для предпринимателей, так и для потребителей это информация о товаре и продавце, способы оплаты, способы получения товаров или услуг, контроль качества и обратная связь 
с обеих сторон. В наши дни в Казахстане не существуют конкурентоспособных маркетплейсов на подобие Amazon или Alibaba. B этом плане меры могут быть предприняты в двух направлениях:

- создание условий для появления собственных мощных маркетплейсов в Казахстане или в рамках Евразийского экономического союза;

- внедрение ограничительных мероприятий в отношении деятельности зарубежных маркетплейсов путем увеличения таможенных сборов.

По первому направлению, прежде всего, необходимо пересмотреть подходы к логистике, развивать сети доставки товаров и расширять спектр банковских услуг. Важной задачей является развитие транспортнологистической инфраструктуры, здесь необходима четкая регламентация деятельности центров хранения. Существование подобных центров позволит существенно сократить сроки доставки, снизить транспортные издержки, выстроить аутсорсинг логистических процессов с частными курьерскими почтами, интернет-магазинами и электронными площадками, в целом упростить ведение бизнеса для малых и средних предприятий.

Наибольший потенциал в качестве базы создания маркетплейсов имеют оптовораспределительные центры, осуществляющие оптовую торговлю продовольственных продуктов. Создание на их базе маркетплейсов позволит субъектам электронной торговли экономить на создании сайта, внедрении системы безналичных платежей, службе доставки, обеспечить условия для реализации отдельных видов сельскохозяйственной продукции за счет организации процессов ее приемки, подработки, первичной переработки, упаковки, надлежащего хранения, ветеринарного и фитосанитарного контроля качества, оптовой торговли, в том числе c использованием автоматизированных электронных информационных и расчетных систем. Здесь показателен опыт Китая и Узбекистана, которые посредством регламентации деятельности оптово-распреелительных центров, предоставили возможность создания маркетплейсов на их основе (Taobao и Agrosale.uz).

$\mathrm{He}$ менее важным является усиление института защиты прав потребителей и введение комплексных мер по защите прав потребителей в сфере электронной коммерции. Необходимо внести изменения в соответствующие регулирующие документы, позволяющие приравнивать права интернет- покупателя с правами традиционного покупателя. Кроме того, для обеспечения прозрачности покупок и снижения рисков, необходимо актуализировать применение «наложенного платежа», подразумевающего сумму денег, которую почта взимает с покупателя товара по поручению продавца. Данный инструмент в Казахстане уже используется в качестве инструмента оплаты безналичных платежей, в АО «Казпочта» - это обычная практика. Однако об его повсеместном применении говорить сложно. Поэтому необходимо провести разъяснительную работу по его признанию как одного из видов инструментов безналичной оплаты.

Существенное значение имеет вопрос повышения цифровой грамотности предпринимателей. В настоящее время Национальной палатой предпринимателей Казахстана ведется обучение базовым цифровым навыкам через сервисную поддержку ведения бизнеса «Выход бизнеса онлайн». Специалистами палаты уже предоставлены консультации более чем 10 тыс. субъектам МСБ, до конца года планируется обучить еще порядка 5 тысяч субъектов МСБ [44]. Кроме того, на базе АО «Казпочта» в городах Нур-Султан, Алматы и Караганда созданы специализированные центры, оказывающие сервисную поддержку предпринимателям в сфере электронной торговли.

Bce вышеперечисленные меры направлены на усиление готовности инфраструктуры и предпринимателей для работы на специализированных площадках электронной коммерции. Однако, создание подобных маркетплейсов находится в интереcax частного сектора, который может на этом получить высокую маржу. В настоящее время пока ни в Казахстане, ни на территории ЕАЭС конкурентоспособных глобальных специализированных площадок, которые позволяют сравнивать поставщиков, цены на товары, условия доставки; выбрать товар, оплатить на той же платформе и получить пока нет.

Если подобный маркетплейс мы будем воспринимать как некую экосистему электронной коммерции, то мы должны понимать, что электронная коммерция активно развивается только при ее наличии. А для появления этой экосистемы требуются огромные инвестиции, которые выражаются в миллионах долларах США. В условиях отсутствия подобной экосистемы, обычно государства используют тарифное регулирование. Так, для защиты внутреннего рынка ЕАЭС были увеличены ставки таможен- 
ных сборов с товаров, получаемых из-за границы. Ранее покупатели могли не проводить таможенную очистку почтовой посылки, если ее стоимость составляла менее 500 евро в месяц. С 1 января 2019 года этот порог был снижен до 200 евро на одну посылку. Предполагается, что к началу 2021 года порог будет снижен до 50 евро, к 2022 году - до 20 евро. При этом, сумма, которая превышает эту норму, облагается пошлиной в $15 \%$. Обложение налогом почтовых отправлений является стандартной мировой практикой. В ЕС малозначительным порогом считается 22 евро, при привышении которого уплачивается НДС. В Индии это всего 1 доллар США. Но рынок Индии очень ёмкий по сравнению с рынком ЕАЭС, поэтому дальнейшее снижение малозначительного порога почтовых отправлений на территории ЕАЭС не целесообразно. Например, крупным площадкам невыгодно торговать в тех странах, где очень низкий порог необлагаемой суммы почтового отправления. Поэтому, в целях экономии средств, компании предпочитают создавать бизнес на территории страны, инвестируя миллиарды долларов в экономику страны для осуществления деятельности, с одной оговоркой - если рынок достаточно привлекателен и емкость рынка большая, как в Индии.

Пока на рынке Казахстана и ЕАЭС в целом не сформирован маркетплейс глобального уровня, местным предпринимателям необходимо выходить на существующие глобальные площадки чтобы продавать отчественные товары за пределами ЕАЭС. Это особенно важно для малых и средних предприятий.

Во-первых, для них в условиях отсутствия необходимой отечественной инфраструктуры стоимость ведения бизнеса в интернете обходится намного выше, так как они вынуждены отдавать на аутсорсинг деятельность, связанную с оплатой, доставкой, возвратом, учетом и разрешением спорных ситуаций.

Во-вторых, малый размер рынка Казахстана не позволяет масштабировать проекты электронной коммерции. По этим причинам отечественным компаниям важно стать частью глобальной экосистемы элеткронной коммерции путем выхода на глобальные рынки. Песпективу с этой точки зрения открывает Alibaba. Однако сложность еe маркетинга и специфики работы требуют определенных навыков от предпринимателей бизнеса. В этом плане государство через свои институты развития и программы может поддержать инициативу включения отечественных предприятий в данную платформу в качестве поставщиков, путем оказания правовой и консультативной помощи.

\section{Заключение}

Результаты проведенного нами анализа позволяют сделать следующие выводы:

1. Исследование сути экономических отношений в электронной коммерции позволило констатировать трансформацию самой теории конкурентных преимуществ в интернет-экономике: если конкурентоспособность в традиционной экономике зависела от производственного потенциала и технологических разработок, то в интернет-экономике конкурентоспособность определяется развитием инфраструктуры электронной коммерции. Без доступа к глобальному рынку, который представляет электронная коммерция, традиционные экономические факторы конкурентоспособности будут бесполезны.

2. Экономическая сущность электронной коммерции заключается в существенном сокращении трансакционных издержек и количества посредников через включение предпринимателей в глобальные цепочки поставок без необходимости нахождения в стране реализации продукции.

3. Присутствие института электронной коммерции нарушает функционирование института традиционной коммерции, ибо рост объемов электронной коммерции происходит в ущерб ритейлу. Однако границы между ними все больше будут стираться в силу того, что ритейлеры будут использовать и традиционные и электронные каналы продаж.

4. Из-за трансграничности электронной коммерции одни страны могут получать бо́льшие выгоды от развития электронной коммерции, другие - убытки от сопутствующей деградации традиционной торговли. Чтобы не оказаться в ряде последних, необходимо государственное вмешательство в сферу электронной коммерции. При этом регулирование должно быть направлено на выравнивание конкурентных условий для зарубежных и отечественных поставщиков, на создание необходимой инфраструктуры электронной коммерции, а также стимулирование предпринимательской активности отечественных предприятий в сфере электронной коммерции путем предоставления налоговых льгот и иных мер поддержки.

5. Эффективное развитие электронной коммерции зависит от таких факторов, как телекоммуникационная инфраструктура и доступность передачи данных, уровень 
цифровой грамотности населения, обеспечение защиты прав потребителей, законодательство, уровень логистической инфраструктуры, а также развитие инструментов безналичной оплаты.

6. Несмотря на отнесение Казахстана к категории стран с высоким уровнем готовности к электронной торговле по UNCTAD B2C E-commerce Index существуют следующие проблемы с инфраструктурой электронной коммерции: отсутствие доступа к высокоскоростным сетям интернета в отдаленных регионах Казахстана или плохое качество соединения; отсутствие существенной конкуренции на рынке почтовых услуг.

7. Результаты исследования показали, что в Казахстане потенциал роста рынка электронной коммерции используется не в полной мере: доля розничной электронной торговли в общей структуре розничной торговли составляет всего 1,8\%. В 2019 г. из 100 тенге совершенных казахстанцами онлайн-покупок 72 тенге остались в Казахстане, в 2018 г. - 76 тенге. Можно предположить, что если Казахстан в ближайшее время не создаст соответствующую инфраструктуру электронной коммерции, то внутренний рынок Казахстана может перейти под контроль зарубежных субъектов электронной коммерции.

8. В плане предоставления налоговых льгот субъектам электронной коммерции, мы придерживаемся мнения о нецелесообразности отмены НДС, так как эта норма распространятся на все субъекты электронной коммерции, что, во-первых, снижает налогооблагаемую базу, во-вторых, ставит местных предпринимателей в неравные конкурентные условия с зарубежными поставщиками, которые не уплачивают подоходный налог в отличие от местных поставщиков.

9. Наиболее оправданным инструментом стимулирования отечественных предпринимателей является отмена подоходного налога. Однако в практике Казахстана применение данного инструмента не показало достаточную эффективность по причине завышенных требований к получателям подобной льготы, выраженных в необходимости взимания 90\% оплат безналичными платежами, в то время, как доля безналичного оборота большинства предприятий электронной коммерции не превышает $35 \%$. В этой связи нами предложено снизить порог безналичного оборота для малых и средних предприятий с 90 до $50 \%$ с ежегодным увеличением на 7-8\%. Такие поправки позволили бы охватить льготами как можно большее количество МСБ электронной коммерции.

10. Создание собственных специализированных платформ электронной коммерции способствует активному ее развитию, поэтому важным в этом контексте представляется создание необходимых условий для появления собственных мощных маркетплейсов в Казахстане или в рамках Евразийского экономического союза. Не менее важным является внедрение ограничительных мероприятий в отношении деятельности зарубежных поставщиков путем тарифного регулирования.

11. Необходимость интегрирования казахстанских малых и средних компаний в глобальные платформы электронной коммерции, как Alibaba, продиктована двумя причинами: 1) аутсорсинг деятельности, связанной с оплатой, доставкой, возвратом, учетом товаров и разрешением спорных ситуаций для малых и средних компаний увеличивает стоимость ведения бизнеса в интернете и делает их неконкурентоспособными; 2) малый размер рынка Казахстана не позволяют масштабировать проекты электронной коммерции. Вкючение в глобальную сеть поставок позволит им сократить трансакционные издержки, увеличить охват рынка без присутвия в стране продаж. Ввиду отсутствия необходимых цифровых навыков у казахстанских предпринимателей, государству необходимо поддержать их в форме оказания консультативной и правовой помощи для выхода на крупные маркетплейсы.

\section{Список использованных источников}

1. Bell D. The Coming of Post-Industrial Society: A Venture in Social Forecasting - New York: Basic Books, 1999. - 507 p.

2. Evans P.B., Wurster T.S. Strategy and the new economics of information // Harvard business review. - 1997. - № 75 (5). - P. 70-82

3. Leamer E.E., Storper M. The economic geography of the internet age // Journal of International Business Studies. - 2001. - № 32 (4). - P. 641-665

4. Czernich N., Falck O., Kretschmer T., Woessmann L. Broadband Infrastructure and Economic Growth // Economic Journal. - 2011. - № 121 (552). - P. 505-532

5. Porter M. Strategy and the Internet // Harvard business review. - 2001. - № 79 (3). - P. 62-78

6. Litan R.E., Rivlin A.M. Projecting the economic impact of the internet // American Economic Review. - 2001. - № 91 (2). - P. 313-317

7. Kosiur D. R. Understanding Electronic Commerce - Redmond, Washington: Microsoft Press, 
1997. $-287 \mathrm{p}$.

8. Amor D. The e-business (r)evolution living and working in an interconnected world. - NJ: Prentice Hall PTR in Upper Saddle River, 2000. - 636 p.

9. Haig M. E-Business Essentials. - London: Kogan Page, 2005. - 128 p.

10. Gary P. Electronic Commerce. Ninth Edition. - United States of America: Schneider, 2017. $-624 \mathrm{p}$.

11. Friberg R., Ganslandt, M., Sandström M. E-commerce and prices - theory and evidence. -SSE/ EFI Working Paper Series in Economics and Finance, Stockholm School of Economics, 2000. No 389, https:// EconPapers.repec.org/RePEc:hhs:hastef:0389

12. Friberg R., Ganslandt M., Sandström M. Pricing Strategies in E-Commerce: Bricks vs. Clicks. Working Paper Series, Research Institute of Industrial Economics, 2001. - No 559. https://EconPapers.repec. org/RePEc:hhs:iuiwop:0559

13. Smith M., Bailey J. and Brynjolfsson E. Understanding digital markets: review and assessment. - MIT Press, 1999. - 34 p.

14. Kauffman R.J., Walden E.A. Economics and electronic commerce: Survey and directions for research // International Journal of Electronic Commerce. - 2001. - № 5 (4), Pp. 5-116

15. Кобелев О.А. Электронная коммерция: Учеб. пособие / Под ред. С.В. Пирогова. - 3-е изд., перераб. и доп. - М.: Издательско-торговая корпорация «Дашков и К», 2008. - 684 с.

16. Балабанов И.Т. Электронная коммерция. - СПб: Питер, 2011. - 336 с.

17. Грехов А.М. Электронный бизнес (Е-коммерция): учебное пособие - К.:Кондор, 2008. $-302 \mathrm{c}$.

18. Климченя Л.С. Электронная. Коммерция - Минск: Высш школа, 2004. - 191 с.

19. Кобелев О.А. Электронная коммерция: учебное пособиею - 2011. - 674 с.

20. Царев В.В., Кантаравич, А.А. Электронная. Коммерция. - СПб:. Питер, 2002. $320 \mathrm{c}$.

21. Рейман Л. Д. Электронная коммерция: учеб. пособие / Под ред. Л. Д. Реймана. - М.: НТЦ «ФРИОД-ИНФО», 2002. - 272с

22. Сигел Д. Шагни в будущее. Стратегия в эпоху электронного бизнеса. - М.: Олимп-бизнес, 2011. -384 c.

23. Савельев А. Электронная коммерция в России и за рубежом. - М.: Статут, 2014. - 544c.

24. Дик В.В., Лужецкий М.В., Родионов А.Э. Электронная коммерция. - М.:Московская финансово-промышленная академия, 2005. - 376 с.

25. Крымский И.А., Павлов К.В. Проблемы и перспективы развития электронной экономики в России. - Мурманск: Изд-во Кольского НЦ РАН, 2007. - 187 с.

26. Стрелец И.А. Сетевая экономика: учебник. - М.: Эксмо, 2006. - 208 с.

27. Lee H.G., Clark T.H. Impacts of the electronic marketplace on transaction cost and market structure // International Journal of Electronic Commerce. - 1996. - № 1(1), - P. 127-149
28. Kotler P., Armstrong G. Principles of Marketing. - 17th. ed. Global Edition. Pearson, 2017. $-736 \mathrm{p}$.

29. Koch R. The Financial Times guide to strategy: how to create and pursue a winning strategy. 4th ed. London: Prentice Hall, 2011. - 392 p.

30. Bowles S. Microeconomics: Behavior, Institutions, and Evolution. Princeton University Press, 2003. - 599 p.

31. Бергер Э. Дж. Е-коммерция и цепи поставок: ломка прежних границ. Управление цепями поставок / под ред. Дж. Л. Гатторны. - М.: Инфра-М, 2008. - 670 с.

32. Калужский M. Л. Приоритеты институционального регулирования электронной коммерции: Россия и мировые тенденции // Приоритеты России. - 2013. - № 42 (231) - C.11-22

33. Doernberg R. \& Hinnekens L. Electronic Commerce and International Taxation. - Boston: Kluwer Law International, 1999. - 380 p.

34. Frieden K. Cybertaxation: The Taxation of E-Commerce. - Chicago, IL: CCH Incorporated and Arthur Andersen LLP, 2000. - 585 p.

35. Hellerstein W. Internet Tax Freedom Act Limits States' Power to Tax Internet Access and Electronic Commerce // Journal of Taxation. - 1999. № 90. - P. 5-10.

36. Корень А.В. Налогообложение субъектов электронной коммерции: проблемы и перспективы. Владивосток: ВГУЭС, 2010. - 176 с.

37. Жанбозова А.Б., Азатбек Т.А., Жуманазаров К.Б. Вопросы налогообложения субъектов электронной коммерции в Казахстане // «Учет, статистика и аудит», 2020. - № 1 (76). C. $222-226$

38. Российский eCommerce и eGrocery в 2019 году: аналитика JP Morgan. Журнал об электронной коммерции E-pepper. 18 Мая 2020. URL: https:/e-pepper.ru/news/rossiyskiy-ecommercev-21019-godu-analitika-jp-morgan.html (Дата обращения: 20.07.2020)

39. Panzabekova A.Zh., Zhanbozova A.B., Zhumanazarov K.B. Electronic public involvement: modern challenges for Kazakhstan // Reports of the National academy of sciences of the Republic of Kazakhstan. - 2020. - № 1 (329). - P. 147-153. https:// doi.org/10.32014/2020.2518-1483.19

40. UNCTAD B2C E-COMMERCE INDEX 2019 // United Nations Conference on Trade And Development. [Электронный ресурс]. URL: https:// unctad.org/system/files/official-document/tn_unctad ict4d14_en.pdf (Дата обращения: 23.07.2020)

41. Каримова Дж. Около 130 тыс жителей Казахстана не получат интернет в этом году // LS [Электронный pecypc]. URL: https://sm.kz/vkazahstane-okolo-130-tys-chelovek-ostanutsya-bezinterneta (Дата обращения: 23.07.2020)

42. Какое будущее у электронной торговли в Казахстане // Zakon.kz [Электронный ресурс]. URL: https://www.zakon.kz/4940532-kakoe-budushcheeu-elektronnoy-torgovli.html (Дата обращения: 29.08.2020) 


\section{References}

1. Bell D. (1999). The Coming of PostIndustrial Society: A Venture in Social Forecasting New York: Basic Books, 507.

2. Evans P.B., Wurster T.S. (1997) Strategy and the new economics of information. Harvard business review, 75 (5), 70-82

3. Leamer E.E., Storper M. (2001). The economic geography of the internet age. Journal of International Business Studies, 32 (4), 641-665

4. Czernich N., Falck O., Kretschmer T., Woessmann L. (2011). Broadband Infrastructure and Economic Growth. Economic Journal. № 121 (552), $505-532$

5. Porter M. (2001). Strategy and the Internet. Harvard business review, № 79 (3), 62-78

6. Litan R.E., Rivlin A.M. (2001). Projecting the economic impact of the internet. American Economic Review. № 91 (2). 313-317

7. Kosiur D. R. (1997). Understanding Electronic Commerce. Redmond, Washington: Microsoft Press, 287.

8. Amor D. (2000). The e-business (r) evolution living and working in an interconnected world. - NJ: Prentice Hall PTR in Upper Saddle River, 636.

9. Haig M. (2005). E-Business Essentials. London: Kogan Page, 128.

10. Gary P. (2017). Electronic Commerce. Ninth Edition. United States of America: Schneider, 624.

11. Friberg R., Ganslandt, M., Sandström M. (2000). E-commerce and prices - theory and evidence. SSE/EFI Working Paper Series in Economics and Finance, Stockholm School of Economics, No 389, https://EconPapers.repec.org/RePEc:hhs:hastef:0389

12. Friberg R., Ganslandt M., Sandström M. (2001). Pricing Strategies in E-Commerce: Bricks vs. Clicks. - Working Paper Series, Research Institute of Industrial Economics, No 559. https://EconPapers. repec.org/RePEc:hhs:iuiwop:0559

13. Smith M., Bailey J. and Brynjolfsson E. (1999).Understanding digital markets: review and assessment. MIT Press, 34.

14. Kauffman R.J., Walden E.A. (2001). Economics and electronic commerce: Survey and directions for research. International Journal of Electronic Commerce. № 5 (4), 5-116

15. Kobelev O.A. (2008). Jelektronnaja kommercija: Ucheb. Posobie. M.: Izdatel'sko-torgovaja korporacija «Dashkov i K», 684.

16. Balabanov I.T. (2011). Jelektronnaja kommercija. SPb: Piter, 336.

17. Grehov A. M. (2008). Jelektronnyj biznes (E-kommercija): uchebnoe posobie. K.:Kondor, 302.

18. Klimchenja L. S. (2004). Jelektronnaja. Kommercija. Minsk: Vyssh shkola, 191.

19. Kobelev O.A. (2011). Jelektronnaja kommercija: Uchebnoe posobie, 674.

20. Carev V. V. (2002). Jelektronnaja. Kommercija. SPb:. Piter, 320 p.

21. Rejman L. D. (2002). Jelektronnaja kommercija: ucheb. posobie. M.: NTC «FRIOD-INFO», 272
22. Sigel D. (2011). Shagni v budushhee. Strategija $\mathrm{v}$ jepohu jelektronnogo biznesa. M.: Olimpbiznes, 384 .

23. Savel'ev A. (2014). Jelektronnaja kommercija v Rossii i za rubezhom. M.: Statut, 2014, 544.

24. Dik V.V. Luzheckij M.V., Rodionov A.Je. (2005). Jelektronnaja kommercija. M.: Moskovskaja finansovo-promyshlennaja akademija, 376.

25. Krymskij I.A., Pavlov K.V. (2007). Problemy i perspektivy razvitija jelektronnoj jekonomiki v Rossii. - Murmansk: Izd-vo Kol'skogo NC RAN, 187.

26. Strelec I.A. (2006). Setevaja jekonomika: uchebnik. M.: Jeksmo, 208.

27. Lee H.G., Clark T.H. (1996). Impacts of the electronic marketplace on transaction cost and market structure. International Journal of Electronic Commerce. № 1(1), 127-149

28. Kotler P., Armstrong G. (2017). Principles of Marketing. 17th. ed. Global Edition. Pearson, 736.

29. Koch R. (2011). The Financial Times guide to strategy: how to create and pursue a winning strategy. 4th ed. London: Prentice Hall, 392.

30. Bowles S. (2003). Microeconomics: Behavior, Institutions, and Evolution. Princeton University Press, 599.

31. Berger Je. Dzh. (2008). E-kommercija i cepi postavok: lomka prezhnih granic. Upravlenie cepjami postavok. M.: Infra-M, 670.

32. Kaluzhskij M. L. (2013). Prioritety institucional'nogo regulirovanija jelektronnoj kommercii: Rossija i mirovye tendencii. Prioritety Rossii. № 42 (231), 11-22

33. Doernberg R. \& Hinnekens L. (1999). Electronic Commerce and International Taxation. Boston: Kluwer Law International, 380.

34. Frieden K. (2000). Cybertaxation: The Taxation of E-Commerce. Chicago, IL: $\mathrm{CCH}$ Incorporated and Arthur Andersen LLP, 585.

35. Hellerstein W. (1999). Internet Tax Freedom Act Limits States' Power to Tax Internet Access and Electronic Commerce. Journal of Taxation. № 90, 5-10.

36. Koren A.V. (2010). Nalogooblozhenie sub\#ektov jelektronnoj kommercii: problemy i perspektivy. Vladivostok: VGUJeS, 176.

37. Zhanbozova A.B., Azatbek T.A., Zhumanazarov K.B. (2020). Voprosy nalogooblozhenija subektov jelektronnoj kommercii V Kazahstane. Uchet, statistika i audit, 1 (76), 222 -226

38. Rossijskij eCommerce i eGrocery v 2019 godu: analitika JP Morgan. Zhurnal ob jelektronnoj kommercii E-pepper. 18 Maja 2020. URL: https:/epepper.ru/news/rossiyskiy-ecommerce-v-21019-goduanalitika-jp-morgan.html (Date of access: 20.07.2020)

39. Panzabekova A.Zh., Zhanbozova A.B., Zhumanazarov K.B. (2020). Electronic public involvement: modern challenges for Kazakhstan. Reports of the National academy of sciences of the Republic of Kazakhstan, 1 (329), 147-153. https://doi. org/10.32014/2020.2518-1483.19

40. UNCTAD B2C E-commerce index 2019 United Nations Conference on Trade And Development. 
URL: https://unctad.org/system/files/official-document/ tn_unctad_ict4d14_en.pdf (Date of access: 23.07.2020)

41. Karimova Dzh. Okolo 130 tys zhitelej Kazahstana ne poluchat internet $\mathrm{v}$ jetom godu - URL: https://lsm.kz/v-kazahstane-okolo-130-tys-chelovekostanutsya-bez-interneta (Date of access: 23.07.2020)
42. Kakoe budushhee u jelektronnoj torgovli v Kazahstane. URL: https://www.zakon.kz/4940532kakoe-budushchee-u-elektronnoy-torgovli.html (Date of access: 29.08.2020)

\section{Сведения об авторах}

Жанбозова А.Б. - корреспондирующий автор, научный сотрудник Института экономики КН МОН PK, PhD-доктарант ЕНУ им. Л.Н. Гумилёва, e-mail: aksaulew@mail.ru, ORCID iD: https://orcid.org/0000-0002$7143-5680$

Азатбек Т.А. - д.э.н., профессор, ЕНУ им. Л.Н. Гумилёва, e-mail: tolkyn_d2005@mail.ru, ORCID iD: https://orcid.org/0000-0002-8985-8905

Валиева С.Н. - PhD, ст. преподаватель кафедры «Менеджмент» Казахского университета экономики, финансов и международной торговли, е-mail: saltanat.valieva.75@mail.ru, ORCID iD: https://orcid.org/00000003-2837-4066

Тузелбаева И.Н. - к.э.н., ст. преподаватель кафедры «Менеджмент» Казахского университета экономики, финансов и международной торговли, e-mail: Inaisha@mail.ru, ORCID iD: https://orcid.org/00000001-5889-5052

Жуманазаров К.Б. - к.э.н., доцент, Казахский университет технологии и бизнеса, e-mail: kaseke63@ inbox.ru ORCID iD: https://orcid.org/0000-0002-0468-1283

\section{Information about the authors}

Zhanbozova A. B. - corresponding author, Researcher of the Institute of Economics of the KN MES RK, PhD-doctoral student of the L. N. Gumilyov ENU, e-mail: aksaulew@mail.ru, ORCID iD: https://orcid.org/00000002-7143-5680

Azatbek T. A. - Doctor of Economics, Professor, L. N. Gumilyov ENU, e-mail: tolkyn_d2005@mail.ru, ORCID iD: https://orcid.org/0000-0002-8985-8905

Valieva S. N. - PhD, Senior Lecturer, Department of Management, Kazakh University of Economics, Finance and International Trade, e-mail: saltanat.valieva.75@mail.ru, ORCID iD: https://orcid.org/0000-0003-2837-4066

Tuzelbaeva I. N. - Candidate of Economics, Senior Lecturer of the Department of Management of the Kazakh University of Economics, Finance and International Trade, e-mail: Inaisha@mail.ru , ORCID iD: https://orcid. org/0000-0001-5889-5052

Zhumanazarov K. B. - Associate Professor, Kazakh University of Technology and Business, e-mail: kaseke63@inbox.ru ORCID iD: https://orcid.org/0000-0002-0468-1283

Дата поступления рукописи: 20.11.2020

Прошла рецензирование: 19.02.2021

Принято решение о публикации: 03.03.2021

Received: 20.11.2020

Reviewed: 19.02.2021

Accepted: 03.03.2021

Қарастыруға қабылданды: 20.11.2020

Рецензиялауды өтті: 19.02.2021

Жариялауга қабылданды: 03.03.2021 